Мила Ђуричић

Универзитет у Новом Саду

Технички факултет „Михајло Пупин“

Катедра за основне и примењене науке

puskinistkinja@gmail.com
УДК 811.161.1:37

https://doi.org/10.18485/slavistika.2020.24.2.34

прегледни рад

примљено 07.04.2020.

прихваћено за штампу 18.09.2020.

\title{
РУСКИ ЈЕЗИК НА ТЕХНИЧКОМ ФАКУЛТЕТУ У ЗРЕЊАНИНУ - АКТУЕЛНО СТАЬЕ И ПЕРСПЕКТИВЕ
}

Рад представља увид у методику наставе руског језика као обавезног предмета на Техничком факултету „Михајло Пупин“ у Зрењанину. Циљ нашег рада представља упознавање читалаца са статусом руског језика и системом реализације наставе на овој високошколској установи. У раду ћемо искористити и анализирати елементе анкетног упитника студената, помоћу којих уочавамо колико план и програм предмета одговарају актуелном стању у пракси.

Кључне речи: методика наставе руског језика, Технички факултет „Михајло Пупин“, истраживање, језик струке, Катедра за нафту и гас, пројекат „Енергија знања“.

The paper presents an insight into the methods of teaching the Russian language as a compulsory course at the "Mihajlo Pupin" Faculty of Technical Sciences in Zrenjanin. The purpose of our paper is to familiarize the audience with the status of Russian language and the educational system at the mentioned faculty. In this paper we will use and analyze the elements of the student survey, which will help us to determine how much the curriculum of subjects corresponds to the current situation in practice.

Keywords: teaching methods of Russian language, "Mihajlo Pupin" Faculty of Technical Sciences, research, language for specific purposes, Department of Oil and Gas, "Energy of Knowledge" project.

\section{Методика - это как, Р.Л. Златогорская ${ }^{1}$}

Технички факултет „Михајло Пупин“ (у наставку текста ТФ) у Зрењанину у децембру 2019. године званично прославља своју четрдесетпетогодишњицу и незванично петогодишњицу постојања Катедре за индустријско инжењерство у експлоатацији нафте и гаса (у даљем тексту Катедра). До сада смо се сретали са чињеницом да се на нефилолошким факултетима руски језик налази у незавидном положају, где има статус изборног језика, а студенти, вођени популаризацијом и личним жељама, у изборној језичкој трци предност дају романским или германским језицима. Оснивањем поменутог смера појављује се руски језик као обавезан други страни језик у курикулуму једног техничког факултета. То нас је навело да прикажемо: (1) кратак историјат оснивања Катедре, (2) организацију наставе и (3) резултате испитивања студентског мишљења о потребама за овим страним језиком и њиховим тренутним постигнућима.

Катедра је настала на иницијативу компаније НИС, која донацијама и кон-

\footnotetext{
${ }^{1}$ „Методика представља начин“, Р. Л. Златогорска. Сви преводи цитата на српски језик су наши.
} 
тактима омогућава несметану делатност ове најмлађе катедре поменутог факултета. Организација Катедре усклађена је по угледу на факултете из региона и света, нарочито на два еминентна руска универзитета - московски РДУ нафте и гаса „И. М. Гупкин“ и ухтински Државни технички универзитет са којим ТФ има потписан уговор о сарадњи. ${ }^{2}$ Формирањем Катедре и обучавањем новог кадра за све популарније послове на тржишту рада - инжењере нафте и гаса, не чуди нас зашто је увођење руског језика на овај смер у образовном систему природан и логичан корак. У плановима будуће акредитације, поред измена других недостатака, остављена је могућност да се руски језик уведе на трећу годину основних и мастер студија. Замишљен план је изврстан - читав садржај предмета био би усмерен искључиво на језик струке. Сада нам се чини да су студенти друге године, када се први пут упознају са терминологијом, оптерећени комплекснијом руском граматиком, а да језик струке усвајају успутно.

\section{Настава почетног и стручног руског језика на ТФ}

Планирање и реализацију наставе руског језика на Катедри условно ћемо поделити и представити из два сегмента - прво као наставу почетног, а затим стручног језика. Питања која су нас заинтересовала у истраживању јесу: (1) да ли студенти након положених испита на првој години достижу ниво знања језика прописан курикулумом, (2) које су њихове способности према Заједничком европском оквиру за живе језике и (3) да ли су након четири семестра оспособљени за коришћење стручне литературе. Како бисмо указали на потенцијалне предности и мане текућих програма, неопходно је да изложимо циљеве, исходе и садржаје свих предмета.

По текућој акредитацији усвајање елементарних језичких компетенција на првој години основних студија траје годину дана (предмети Руски језик 1 и 2). Настава почетног руског остварује се два пута недељно путем предавања и вежби. Главни материјал представља уџбеник Лестница (аутора М. Н. Аникине) и практикум са вежбањима. Требало би да током годину дана студенти овладају свим језичким вештинама на елементарном нивоу. Њихово знање језика тада би требало да одговара нивоу А1 према Заједничком европском оквиру за живе језике.

По плану и програму предмета ${ }^{3}$ Руски језик 1 циљ је дефинисан на следећи начин: „Формирање артикулационе базе, савладавање руске графије, почетно формирање навика аудирања, говорења, читања и писања у оквиру ограниченог броја тема и ситуација на елементарном нивоу“; садржај: „Упознавање са руским фонетским системом, основама морфологије и синтаксе (категорија рода, броја и падежа, номинатив, акузатив и локатив једнине и множине деклинабилних врста речи, инфинитива глагола, садашње време, прошло време, проста

\footnotetext{
${ }^{2}$ Ову чињеницу сматрамо једном од најважнијих досадашњих међународних успеха с обзиром да су студенти у могућности да бораве у руској средини и да, поред професионалних, усавршавају и стручне компетенције.

${ }^{3}$ Све курикулуме наводимо према: Документацији за акредитаџију студијског програма Индустријско инжењерство у експлоатацији нафте и гаса. (в. Литература).
} 
или просто-проширена реченица). Лексика и фразеологија у складу са темама из прве половине уџбеника“; исход: „На крају курса студент би требало да зна основна правила фонетике, графије и ортографије, да стекне навике правилног изговора руских гласова, да уме да прочита, каже, разуме на слух и напише на елементарном нивоу неколико реченица о себи и околини у складу са темама и текстовима из прве половине уџбеника (првих 10 лекција)“.

Упознавање са језичким вештинама наставља се на предмету Руски језик 2, где се циљ наставе сагледава кроз: „Развијање навика аудирања, говорења, читања и писања у оквиру ограниченог броја тема и ситуација на елементарном нивоу, што приближно одговара нивоу A1 Заједничког европског оквира за живе језике“; садржај: „Теме покривене лекцијама из уџбеника (11-21), у којима је заступљена одговарајућа фонетска, морфолошка и синтаксичка грађа (основни обрасци промене деклинабилних врста речи; основни бројеви, слагање именица уз бројеве; глаголи: презент, перфекат, глаголски вид, сложени и прости футур, инфинитив и промена повратних глагола, основни вид глагола, основни глаголи кретања; сложена реченица). Вокабулар у складу са темама које се обрађују у уџбенику“, а исход: „На крају курса требало би да студент поседује формиране вештине читања, говорења, аудирања и писања на нивоу приближном A1 Заједничког европског оквира за живе језике, тј. да је у стању да разуме и употребљава фамилијарне и свакодневне речи и изразе у једноставним реченицама у циљу задовољавања свакодневних потреба“.

Методе извођења наставе током свих предмета представљају комбинацију традиционалне и комуникативно-когнитивне методе: „ <..> кроз интеракцију са предавачем и међусобну интеракцију студенти развијају вештине читања, писања, говорења и аудирања, усвајају вокабулар и граматичке јединице примерене њиховом нивоу владања језиком, а према материјалу који пружа уџбеник $<\ldots>^{* 4}$. Сматрамо да је у пракси реализација замишљеног отежавајућа због неједнаког нивоа почетног знања, недовољне мотивације студената за учешће у разговорима, а надасве мало предвиђених часова. У таквој ситуацији, иако говоримо о техничком факултету, неопходно је укључивање и ваннаставних активности. 5 Анализом курикулума предмета закључујемо да су све језичке вештине довољно заступљене, а да граматичко-лексички садржај, према руским и српским стандардима, у потпуности одговара елементарном нивоу: „Корисник може да разуме кратке, једноставне текстове читајући фразе, издвајајући позната имена, речи или, ако је неопходно, поновним читањем <... >“ (Балыхина 2007: 142), односно, „Osoba koja je dostigla ovaj nivo može razumjeti jednostavne rečenice, na primjer, u oglasima, obaveštenjima i katalozima." (Zajednički okvir za strane jezike 2003: 247).

На другој години студија студенти настављају учење језика користећи уџбеник Дорога в Россию. Учебник русского языка (первый уровень 1) аутора В. J. Антонове, М. М. Нахабине, А. А. Толстих, док се са терминологијом упознају усвајајући материјал књиге $O$ нефти по-русски аутора Ј. В. Јермакове, О. В.

\footnotetext{
${ }^{4}$ Према: курикулум предмета Руски језик 1 u 2.

${ }^{5}$ Видећемо да је једна од студентских асоцијација на руски језик био „хор“, тј. додатна активност.
} 
Константинове, А. А. Муравјове.

Из курикулума видимо да се од студената очекује владање језиком на нивоу A2 (предмет Руски језик 3): циљ предмета: „Даље развијање говорних вештина читања, говорења, аудирања и писања приближно до нивоа A2 Заједничког европског оквира за живе језике“; садржај: „Теме покривене лекцијама из прве половине уџбеника у којима је заступљена одговарајућа лексика и граматичка грађа (прелазни и непрелазни глаголи, активне и пасивне конструкције с глаголима НСВ и СВ, повратни глаголи, активни и пасивни партиципи садашњег и прошлог времена, грађење активних партиципа и промена по падежима, њихово место у реченици; пасивни партиципи садашњег и прошлог времена, грађење пасивних партиципа и промена по падежима, краћи облик партиципа)“; исход: „На крају курса студент би требало да развије вештине читања, писања, слушања и говорења приближно нивоу А2 Заједничког језичког оквира за живе језике, да савлада лексички и граматички материјал презентован у претходном уџбенику и да стекне шира културолошка знања о Русији и Русима.“

Као што смо рекли на почетку, стручно поље је остало резервисано за последњу годину учења у оквиру претходног и новог курса - Руски језик 4. Циљ наставе јесте: „Даље развијање језичких вештина (читања, писања, слушања и говорења), као и овладавање вокабуларом и граматичким јединицама у складу са темама и текстовима из уџбеника приближно нивоу Б1 према Заједничком европском оквиру за живе језике“; садржај: „Тематика и лексика заступљена у лекцијама из друге половине уџбеника. Наставак рада са преводом и разумевањем стручних текстова из друге половине уџбеника $O$ нефти порусски. Граматички садржаји: промена и употреба основних и редних бројева; глаголски прилози несвршеног и свршеног вида: значење, грађење и употреба; изражавање мере и степена у сложеној реченици“, а исход: „На крају курса студент би требало да буде у стању да разуме суштину конкретних или апстрактних садржаја у тематски, стилски и жанровски разноврсним текстовима, као и стручну расправу из своје области, да усавршава вештине и умеће практичког владања руским језиком у професионалној сфери комуникације. Студент такође треба да буде добро упознат са терминолошким материјалом и спецификом научног стила у комуникацији“. Уочавамо да се од студената очекује владање језиком на нивоу Б1, тачније, према стандардима постигнућа, студенти су способни за следеће: „Корисник може да чита једноставне текстове који садрже чињеничне информације и да их довољно добро разуме; може да разуме описе догађаја, осећања и жеља у личним писмима (у редовном дописивању са пријатељем); може да пронађе и схвати актуелне информације у свакодневном материјалу: брошурама, кратким званичним документима; може да спозна главну идеју расуђивања о теми, закључке усмерене ка доказивању одређене тачке гледишта, да схвати правила (сигурносна, на пример), ако су написана једноставним језиком.“ (Балыхина 2007: 142), тј. „Osoba koja dostigne ovaj nivo može da razumje tekstove koji sadrže standardni jezik ili jezičku terminologiju sa posla. Može da razumje lična pisma u kojima se opisuju događaji, osjećanja ili želje.“ (Zajednički okvir za strane jezike 2003: 247).

С обзиром на то да је план и програм учења руског језика усмерен на једногодишње усвајање терминологије, природно се поставља питање да ли 
је предвиђени временски период довољан за главне циљеве језика струке - , $<\ldots>$ оспособљавање студената за самостално читање и служење стручном литературом и разменом знања и информација првенствено у сфери професионалне комуникације“ (Папрић 2016: 36), којима би требало тежити на техничком факултету.

\section{Анализа студентске анкете и дискусија}

У анонимном анкетном испитивању спроведеном онлајн у марту 2020. године учествовало је шездесет испитаника (16 студената прве године, 20 друге, 11 треће, 11 четврте и 2 апсолвента) $)^{6}$, који су одговарали на четрнаест питања. У нашем истраживању већина испитаника је била мушког пола (однос је био 53,3\% спрам 46,7\%). Интересантно је да 73,3\% њих нису учили руски пре факултета, а да 93,3\% сматра да би требало учити руски на Катедри. Видели смо да већина студената пре студија није учила руски. Постојећи курикулуми предмета Руски језик 1 и 2 јесу у потпуности адаптирани према тој чињеници. Један од најважнијих закључака који смо добили огледа се у практичној употреби језика $-93,3 \%$ испитаника тврди да ће им знање руског језика користити у одабраној професији. Знајући да се поједини испитаници први пут сусрећу са учењем руског, сматрали смо да је неопходно испитати њихову способност читања (са разумевањем текста), најзаступљенију језичку вештину у настави руског језика у српским школама, донекле и на (нефилолошким) факултетима: „Пракса, искуство и ставови методичара о учењу генетски сродних језика показали су да српски аудиторијум од четири језичке вештине - слушање, писање, говорење и читање - најбоље савладава последњу.“ (Ђуричић 2017: 251-252). Са друге стране, желели смо да испитамо могућност комуникације на руском језику, прецизније - да ли су студентска постигнућа приближна нивоу Б1 према Заједничком језичком оквиру за живе језике дефинисани циљем предмета Руски језик 4. Дошли смо до закључка да испитаници владају овом језичком вештином на средњем нивоу - 46,7\% испитаника је своје компетенције оценило тројком, $35 \%$ четворком, $10 \%$ петицом, а занемарљив проценат двојком и јединицом $(6,7 \%$ и $1,7 \%)$. Овај податак не треба да чуди, с обзиром да „, $<.>$ српски говорник уз основна знања фонетике, морфологије и творбе речи може да разуме или наслути значење више од 50\% речи руског језика““ (Гинић 2016: 187-188), а захваљујући генетској сродности. Другачије резултате доноси испитивање могућности комуникације на руском језику: само један испитаник је одговорио да је потпуно спреман (оцена 5), 20\% њих оценили су своје компетенције четворком, $30 \%$ тројком, $38,3 \%$ двојком, а 10\% јединицом.

Већ смо указали на проблематичност реализације комуникације. Водећи разлог таквог стања најпре треба тражити у недовољном броју предвиђених часова и великим групама. Како би се комуникација несметано обављала, неопход-

${ }^{6}$ Требало би имати у виду да је на Катедру 2019/20. године уписано 27 студената на прву годину студија, по 30 на другу и трећу, 40 на четврту годину, али да не похађају сви редовно наставу, самим тим од њих нисмо могли очекивати да учествују у анкетирању. Сматрамо да шездесет испитаника представља довољан узорак за ову врсту истраживања. 
но је увести додатне радионице и рад у мањем окружењу. Проблем неостварене комуникативне функције на страном језику видимо у читавом образовном систему. Потенцијално решење се налази у сваком предавачу, тј. његовом индивидуалном приступу. Полазећи од претпоставке да су студенти заинтересовани за побољшање ове компетенције, долазимо до доказа - наше истраживање је показало да 71,7\% испитаника жели да научи руски језик на нивоу комуникације и разумевања неопходне терминологије за будућу професију (16,7\% интересује искључиво комуникација, а 11,7\% усвајање терминологије).

Одређивањем нивоа познавања језика добили смо занимљиву статистику. Студенти ТФ сматрају да поседују ниво језика између А1 и А2 (интересантно je да су вредности приближне - 40\% њих сматра да поседује ниво A1, 38,3\% испитаника тврди да су овладали језиком на нивоу А2, док је 21,7\% одредило свој ниво језика као Б1). Могући разлог за подударање видимо у недовршеном семестру. Бруцоши су започели ниво A1, а студенти друге године се још увек не осећају сигурно да тврде да су им компетенције више од нивоа А2. Дакле, нашим истраживањем смо показали да тренутно осмишљени план и програм предмета потенцијално осликавају реално стање и студентска постигнућа.

Ако узмемо у обзир главни циљ језика струке, можемо закључити да се настава руског језика на факултету реализује у добром правцу и даје позитивне резултате - 48,3\% испитаника тврди да је након одслушаних курсева руског језика способно за самостално читање и коришћење стручне литературе. Међутим, није занемарљив ни проценат компетентних за комуникацију на руском $-31,7 \%$, док петина испитаника тврди да је способна за оба - 20\%. У вези са тим, значајна већина слаже се да је потребно више времена посветити језику струке (85\%).

Осврнимо се на анализу питања која се тичу наставе. Посебно занимљиви били су одговори на захтев навести минимум два разлога од значаја за квалитетну наставу. Напомињемо да нисмо добили одговор од свих испитаника, а да добијени представљају суштину методичких погледа, вишеструко обрађиваних у науци. Одговори уједно треба да представљају и смернице у креирању наставе и свакодневном обликовању предавача. Према студентима, квалитетна настава подразумева7: (1) доброг професора и добру атмосферу; (2) кратка предаваға са интензивним и занимљивим садржајем; (3) мотивачију за учење и дисциплину; (4) разговарање на руском језику и гледање филмова; (5) интерактивну и занимљиву наставу/материјал; (6) формирање група за вежбање; (7) повећање броја семестара за слушање руског; (8) домаће задатке; (9) више ваннаставних активности; (10) труд. Уочавамо да постоји позитивна клима међу студентима за увођење руског језика на остале године (нивое) студија, по могућству реализовањем наставе у групама. Задржаћемо се на првом одговору, који је заслужно заузео водеће место. Наиме, према другој студентској анкети спроведеној у оквиру наставе енглеског језика на Универзитету у Нишу налазимо карактеристике доброг професора: , <..> да би неко био добар професор, најпре је потребно да буде добар човек, да има разумевање за своје студенте, да буде толерантан и стрпљив, да буде приступачан, да буде објективан, да има ваљано опште

\footnotetext{
${ }^{7}$ Одговори су представљени према учесталости јављања.
} 
образовање, да буде интелигентан, забаван, да има самопоуздања, да буде ауторитативан, а не ауторитаран.“ (Китић 2008: 36). Сматрамо да би се и наши студенти сложили са овим одликама. Говорећи о епитетима професора, у нашој анкети неколико пута се поновио појам „приступачности“. Очигледно су персонализација, доступност и повезивање професора са студентима неке од успешнијих метода наставних стратегија. ${ }^{8}$ Сви одговори требало би да служе као додатни подстрек за квалитетнију наставу, како бисмо смањили следеће прве асоцијације на руски језик9: да ли ћу овај језик икада научити?; глаголи кретања; неозбиљно; учење руске граматике до бесвести итд. Последњи одговор захтева детаљнију анализу. Посматрајући садржај предмета Руски језик 3 , не изненађују нас негативни коментари. Наведено усвајање граматичких јединица на неким факултетима траје неколико семестара, а на техничком факултету сложеније граматичке области руског језика (мислимо на пасив, активне и пасивне партиципе, њихову деклинацију) требало би усвојити за три месеца. Без улагања додатног труда то је практично немогуће. Са друге стране, оправдано је њихово присуство - стручни текст не може постојати без поменутих јединица. Решење овог проблема видимо у новој расподели градива. Претпостављамо да бисмо на тај начин успели да добијемо позитивне асоцијације на наставу руског језика, налик на следеће, добијене анкетирањем: професор; текстови, филмови и стручни текстови; усавриавање; одлична сарадња и интеракиија између професора и студената; вежбе слушањ а; певање у хору; рад, а у исто време опуштање; ишчекивање нечег новог и занимљивог; Москва; НИС; ГАСПРОМ итд. Одговори најбоље потврђују мишљење Пасова (Пассов 2015), који инсистира да методику не треба схватати искључиво као методику наставе страних језика, већ образовањ $а$ на страном језику: „< ..> образовање на страном језику представља образовни утицај који обогаћује човека не само у погледу наставног плана и програма, него и у сва четири аспекта образовања: когнитивном, развојном, васпитном, образовном.“ (Пассов 2015: 63-64) Тиме нас аутор упућује на размишљање о улози методике наставе у формирању човека. Посматрајући кроз такву призму, јасно је да наставник који истовремено и образује има комплекснији задатак.

У актуелној ситуацији, када је положај страног језика на нематичним факултетима нестабилан, а језик често маргинализован и лако замењив, како би се избегло свођење језика на једносеместрални предмет, наставник мора бити стожер одрживости постојећег статуса предмета. У супротном, уколико не нађе начин за превазилажење ове потенцијалне опасности, сноси део одговорности. ${ }^{10}$

\section{Закључак}

На основу свега изнетог мишљења смо да је настава руског језика добро конципирана у погледу циљева и садржаја наставе формулисаних у оквиру про-

\footnotetext{
${ }^{8}$ В. у: Китић, 2008.

${ }^{9}$ Одговори преузети из анкете.

${ }^{10}$ И наше истраживање је показало да се $88,3 \%$ испитаника слаже да наставник представља кључни фактор у мотивацији и учењу језика. О овоме детаљније в. Папрић 2016.
} 
грама. Студенти су оспособљени за један циљ језика струке, док се други може постићи повећањем временског оквира за учење руског језика, поделом на групе и додатним садржајима. У даљим активностима требало би настојати на корекцији става да изван факултета испитаници користе руски језик повремено $(48,3 \%)$, никад $(41,7 \%)$, често $(8,3 \%)$ и свакодневно $(1,7 \%)$, узимајући у обзир које све могућности пружа један страни језик. У вези с тим, сматрамо да би у будућности требало увести руски језик на остале смерове ТФ, чиме би студенти засигурно били оспособљени за коришћење литературе (што је потврдило наше истраживање). Важност тога огледа се у податку да је руски језик „, <..> други после енглеског, по популарности на интернету, према подацима из маја 2016. године <.. >“" (Гинић 2018: 116). Затим би требало размотрити и могућност преласка предавача са Катедре за основне и примењене науке на Катедру, пошто је учење руског језика тренутно доступно само појединим студентима, на основу чега не видимо разлог припадања „општем“.

Коначно, интензивно развијање међународне сарадње, размена наставног кадра и студентског подмлатка са престижним руским и светским универзитетима, рад на промоцији Катедре, укључивање студената у секције и сл. су задаци које је неопходно непрестано извршавати. Добра реформа образовања (у нашем случају Катедре) јесте дуготрајан процес, којем би требало приступити у најскоријем року како би се достигао бољитак и оснаживање. Прва петогодишњица постојања и педесетак дипломираних студената показује да заједничким залагањем овај смер може постати водиља за будућа оснивања сличних студија.

\section{Цитирана литература}

Балыхина, Татьяна М. Методика преподавания русского языка как неродного, нового. Москва: Российский университет дружбы народов, 2007.

[Balykhina, Tat'iana M. Metodika prepodavaniia russkogo iazyka kak nerodnogo, novogo. Moskva: Rossiǐskiı̌ universitet druzhby narodov, 2007]

Гинић, Јелена. „Сегментни и супрасегментни фонетски материјал у уџбеницима руског језика за основну школу“. Живи језици:часопис за стране језике и књижевности, XXXVI, 2016: 187-208.

[Ginić, Jelena. ,Segmentni i suprasegmentni fonetski materijal u udžbenicima ruskog jezika za osnovnu školu“. Živi jezici:časopis za strane jezike i književnosti, XXXVI, 2016: 187-208]

Гинић, Јелена. „Настава руског језика у основној школи: актуелно стање и перспектива“. Језици образовања, 2018: 109-120.

[Ginić, Jelena. „Nastava ruskog jezika u osnovnoj školi: aktuelno stanje i perspektiva“. Jezici obrazovanja, 2018: 109-120]

Ђуричић, Мила. „Постигнућа у разумевању писаног текста на руском језику после општег средњег образовања“. Живи језици:часопис за стране језике и књижевности, XXXVII, 2017: 251-260.

[Đuričić, Mila. „Postignuća u razumevanju pisanog teksta na ruskom jeziku posle opšteg srednjeg obrazovanja“. Živi jezici:časopis za strane jezike i književnosti, XXXVII, 2017: 251-260] 
Китић, Слободанка. „Виготски и настава и учење језика“. [У:] Ј. Вучо (ур.) Мултидисциплинарност у настави језика и књижевности. Никшић: Универзитет Црне Горе, 2008, 35-44.

[Kitić, Slobodanka. „Vigotski i nastava i učenje jezika“. [U:] J. Vučo (ur.) Multidisciplinarnost u nastavi jezika i književnosti. Nikšić: Univerzitet Crne Gore, 2008, 35-44]

Папрић, Маријана. Систем наставе руског језика као језика струке на хуманистичким студијама у српској говорној и социокултурној средини. Београд: Филолошки факултет, 2016. (докторска дисертација)

[Paprić, Marijana. Sistem nastave ruskog jezika kao jezika struke na humanističkim studijama u srpskoj govornoj i sociokulturnoj sredini. Beograd: Filološki fakultet, 2016. (doktorska disertacija)]

Пассов, Ефим. И. Методика как наука будущего. Краткая версия новой концепции. Санкт-Петербург: Златоуст, 2015.

[Passov, Efim. I. Metodika kak nauka buduŝego. Kratkaâ versiâ novoj koncepcii. Sankt-Peterburg: Zlatoust, 2015]

Технички факултет „Михајло Пупин“. Документација за акредитацију студијског програма Индустријско инжењерство у експлоатацији нафте и гаса. Зрењанин: Технички факултет „Михајло Пупин“, 2020.

[Tehnički fakultet „Mihajlo Pupin“. Dokumentacija za akreditaciju studijskog programa Industrijsko inženjerstvo u eksploataciji nafte i gasa. Zrenjanin: Tehnički fakultet „Mihajlo Pupin“, 2020]

Ministarstvo prosvjete i nauke Crne Gore. Zajednički evropski okvir za žive jezike: učenje, nastava i ocjenjivanje. Podgorica: Ministarstvo prosvjete i nauke Crne Gore, 2003.

Мила Джуричич

\section{РУССКИЙ ЯЗЫК НА ТЕХНИЧЕСКОМ ФАКУЛЬТЕТЕ В Г. ЗРЕНЯНИН - СОВРЕМЕННОЕ СОСТОЯНИЕ И ПЕРСПЕКТИВЫ}

\section{Резюме}

В данной статье подаётся обзор основных проблем методики преподавания русского языка в качестве обязательного предмета на Техническом факультете имени Михаила Пупина г. Зренянин. Цель нашей работы - ознакомить читателей с актуальным состоянием преподавания русского языка с точки зрения общей системы обучения в данном вузе. В статье использованы данные студенческого опроса, анализ которых поднимает вопрос о том, насколько учебная программа соответствует реальным запросам студентов.

Ключевые слова: методика преподавания РКИ, Технический факультет имени Михаила Пупина, опрос, Кафедра нефти и газа, язык специальности, проект «Энергия знаний». 